\title{
COMPARATIVE ANALYSIS OF THE USE OF FIXED COMBINATIONS OF DRUGS ACTING ON THE RENIN-ANGIOTENSIN SYSTEM, IN THE REPUBLIC OF SERBIA AND NORDIC COUNTRIES, IN THE PERIOD 2010-2015
}

\author{
Boris Milijašević', Stefan Jovanović', Danilo Medin², Đurđa Cvjetković1, \\ Dragana Milijaševićc ${ }^{3}$, Nataša Tomić ${ }^{4}$, Mladena Lalić-Popović ${ }^{5}$, Nemanja Todorović ${ }^{5}$
}

\footnotetext{
1 Katedra za farmakologiju, toksikologiju i kliničku farmakologiju, Medicinski fakultet, Univerzitet u Novom Sadu, Novi Sad, Srbija

2 Klinika za nefrologiju i kliničku imunologiju, Klinički centar Vojvodine, Novi Sad, Srbija

3 Institut za javno zdravlje Vojvodine, Medicinski fakultet, Univerzitet u Novom Sadu, Novi Sad, Srbija

4 Urgentni centar, Klinički centar Vojvodine, Novi Sad, Srbija

5 Katedra za farmaciju, Medicinski fakultet, Univerzitet u Novom Sadu, Novi Sad, Srbija
}

\section{SAŽETAK}

Uvod: Hipertenzija predstavlja jedan od najznačajnijih faktora rizika za nastanak kardiovaskularnih bolesti (KVB) na koji se može uticati. Kod određenog broja bolesnika regulisanje hipertenzije se može postići kombinovanjem antihipertenziva - primenom dva leka istovremeno ili primenom fiksne kombinacije dve lekovite supstance u jednom doziranom obliku.

Cilj: Cilj rada je bio da se analizira potrošnja fiksnih kombinacija lekovitih supstanci iz podgrupe anatomsko-terapijsko-hemijskog (engl. anatomical-therapeutic-chemical - ATC) sistema klasifikacije lekova C09 (lekovi koji deluju na renin-angiotenzin sistem - RAS), u Republici Srbiji, u periodu od 2010. do 2015. godine. Takođe, cilj je bio i da se dobijeni rezultati uporede sa potrošnjom istih lekova u Kraljevini Norveškoj, Republici Finskoj i Kraljevini Danskoj, za isti vremenski period.

Materijal i metode: Pri izradi rada korišćen je koncept ATC klasifikacije i definisane dnevne doze (DDD). Podaci o potrošnji lekova preuzeti su iz godišnjih izveštaja Agencije za lekove i medicinska sredstva Srbije (ALIMS), Norveškog instituta za javno zdravlje - Folkehelseinstituttet, Finske Agencije za lekove - Fimea i Danske Agencije za zaštitu podataka - Sundhedsdatastyrelsen. Količina potrošenih lekova izražavana je kao broj DDD na 1.000 stanovnika na dan (DDD/1.000 stanovnika/dan).

Rezultati: Potrošnja fiksnih kombinacija inhibitora angiotenzin konvertujućeg enzima (engl. angiotensin-converting enzyme - ACE) i diuretika (CO9BA) u 2010. godini, u Srbiji, iznosila je oko 14\%, dok je u poslednjoj posmatranoj godini

Autor za korespondenciju:

Boris Milijašević

Katedra za farmakologiju, toksikologiju i kliničku farmakologiju

Medicinski fakultet, Univerzitet u Novom Sadu

Hajduk Veljkova 3, 21000 Novi Sad, Srbija

Elektronska adresa: boris.milijasevic@mf.uns.ac.rs

Primljen • Received: April 25, 2020； Revidiran • Revised: June 22, 2020;

\author{
Department of Pharmacology, Toxicology and Clinical \\ Pharmacology, Faculty of Medicine, University of Novi Sad, Novi \\ Sad, Serbia \\ 2 Clinic for Nephrology and Clinical Immunology, Clinical Center of \\ Vojvodina, Novi Sad, Serbia \\ 3 Institute of Public Health of Vojvodina, Faculty of Medicine, \\ University of Novi Sad, Novi Sad, Serbia \\ 4 Emergency Center, Clinical Center of Vojvodina, Novi Sad, Serbia \\ 5 Department of Pharmacy, Faculty of Medicine, University of Novi \\ Sad, Novi Sad, Serbia
}

\section{ABSTRACT}

Introduction: Hypertension is one of the most significant risk factors for the development of cardiovascular disease (CVD) that can be mitigated. In a certain number of patients, the regulation of hypertension can be achieved by combining antihypertensive drugs - by using two medicines at the same time or by applying a fixed combination of two drugs in single dosage form.

Aim: The aim of this study was to analyze the consumption of fixed combinations of drugs from the subgroup of the anatomical-therapeutic-chemical (ATC) system of the $\mathrm{CO}$ drug classification (agents acting on the renin-angiotensin system - RAS), in the Republic of Serbia, in the period from 2010 to 2015. Also, the aim was to compare the obtained results with the consumption of the same drugs in the Kingdom of Norway, the Republic of Finland, and the Kingdom of Denmark, for the same period. menski period.

Materials and methods: The concept of ATC classification and defined daily dose (DDD) was applied. Data on drug consumption were taken from annual reports of the Medicines and Medical Devices Agency of Serbia (ALIMS), the Norwegian Public Health Institute - Folkehelseinstituttet, the Finnish Drug Agency - Fimea and the Danish Data Protection Agency - Sundhedsdatastirelsen. The quantity of the drugs consumed was presented as the number of DDD per 1,000 inhabitants per day (DDD/1,000 inhabitants/day).

Results: The consumption of fixed combinations of angiotensin-converting enzyme (ACE) inhibitors and diuretics (CO9BA) in Serbia, in 2010, amounted to about 14\%, while in the last observed year it amounted to about $18 \%$ of the total consumption

Corresponding author:

Boris Milijašević

Department of Pharmacology, Toxicology and Clinical Pharmacology, Faculty of Medicine, University of Novi Sad

3 Hajduk Veljkova Street, 21000 Novi Sad, Serbia

E-mail: boris.milijasevic@mf.uns.ac.rs

Prihvaćen • Accepted: June 29, 2020; Online first: August 30, 2020. 
iznosila oko 18\% ukupne potrošnje lekova iz podgrupe C09. Potrošnja iste grupe lekova u Norveškoj, u 2010. godini, iznosila je oko 5\%, a u 2015. godini, oko 4\%; u Finskoj je bila nešto veća, i u 2010. godini je iznosila oko 7\%, a u 2015. godini, oko 5\%; dok je u Danskoj, u 2010. godini, iznosila oko 12\%, a u 2015. godini, oko 10\%, od ukupne potrošnje lekova iz podgrupe C09. Potrošnja fiksnih kombinacija antagonista receptora angiotenzina II sa diureticima je u Srbiji veoma mala i iznosi tek oko 1\% ukupne potrošnje lekova koji deluju na RAS.

Zaključak: Potrošnja fiksnih kombinacija antagonista receptora angiotenzina II sa diureticima, u posmatrane četiri države, u analiziranom šestogodišnjem periodu, najmanja je u Republici Srbiji. Takođe, struktura potrošenih fiksnih kombinacija se u velikoj meri razlikuje između Republike Srbije i preostale tri nordijske države.

Ključne reči: definisana dnevna doza, kardiovaskularne bolesti, hipertenzija, renin-angiotenzin sistem

\section{UVOD}

Kardiovaskularne bolesti (KVB) predstavljaju veliku, heterogenu grupu oboljenja. Ove bolesti su vodeći uzrok umiranja u većini razvijenih zemalja, ali i u mnogim zemljama u razvoju. Najznačajniji faktori rizika na koje se može uticati su: povišen krvni pritisak (hipertenzija), pušenje, povišen nivo lipoproteina male gustine (engl. low-density lipoproteins - $L D L$ ), snižen nivo lipoproteina velike gustine (engl. high-density lipoproteins - HDL), diabetes mellitus, gojaznost, neadekvatna ishrana, fizička neaktivnost, i dr. Razvoj KVB je direktno povezan sa povišenjem sistolnog i/ili dijastolnog krvnog pritiska, te je kontrola ovih parametara jedan od glavnih pristupa u prevenciji kardiovaskularnih bolesti $[1,2]$. Procenjuje se da je 2010. godine prevalenca hipertenzije u svetu, u odrasloj populaciji, iznosila 31,1\% [3]. Takođe je poznato da je prevalencija u porastu, kako u adultnoj [3], tako i u pedijatrijskoj populaciji [4]. Međutim, istraživanja su pokazala da se, u pojedinim zemljama, prosečna vrednost krvnog pritiska tokom vremena smanjuje, što ukazuje na razvijenost njihove farmakoterapijske prakse. Takvi podaci su zabeleženi u zemljama kao što su: Norveška [5], Finska [6] i Danska [7]. U Srbiji su sprovedena istraživanja pokazala da je prevalenca hipertenzije značajno viša od svetskog proseka i procenjuje se da iznosi oko 47\% [8], a stope umiranja od bolesti koje su uzrokovane hipertenzijom porasle su za $113,6 \%$, u periodu od 2009. do 2018. godine [9].

Osnovni cilj farmakoterapije hipertenzije jeste izbegavanje rizika koje ona nosi, uz očuvanje normalnog kvaliteta života. Evropsko društvo za hipertenziju i Evropsko društvo za kardiologiju (European Society of Hypertension - ESH; European Society of Cardiology - ESC) preporučuju, kao lekove prvog izbora kojima se može započeti medikamentna terapija u lečenju hipertenzije $[10,11]$, sledeće grupe lekova: diuretike, adrenergičke beta blokatore, blokatore kalcijumskih of drugs from the $\mathrm{CO}$ subgroup. The consumption of the same group of drugs in Norway, in 2010, was about 5\%, and in 2015, about 4\%; in Finland it was slightly higher - in 2010, it was about 7\%, and in 2015, about 5\%; while in Denmark, in 2010, it amounted to about $12 \%$, and in 2015 , to about $10 \%$ of the total consumption of drugs from the $\mathrm{C} 09$ subgroup. The consumption of fixed combinations of angiotensin II receptor antagonists with diuretics is very small in Serbia and amounts to only about $1 \%$ of the total consumption of drugs acting on the RAS.

Conclusion: The consumption of fixed drug combinations of angiotensin II receptor antagonists with diuretics, in the observed four countries, in the analyzed six-year period, was the lowest in the Republic of Serbia. Also, the structure of the fixed combinations of drugs consumed differs greatly between the Republic of Serbia and the remaining three Nordic countries.

Keywords: defined daily dose, cardiovascular diseases, hypertension, renin-angiotensin system

\section{INTRODUCTION}

Cardiovascular diseases (CVD) represent a large, heterogeneous group of illnesses. These diseases are the leading cause of death in most developed countries, as well as in many developing countries. The most important risk factors for CVD that can be mitigated are the following: hypertension, smoking, elevated levels of low-density-lipoproteins (LDL), decreased levels of high-density lipoproteins (HDL), diabetes mellitus, obesity, poor nutrition, physical inactivity, etc. The development of CVD is directly linked to the elevation in systolic and/or diastolic blood pressure, which is why controlling these parameters represents one of the main approaches in the prevention of cardiovascular diseases $[1,2]$. It is estimated that, in 2010, the prevalence of hypertension in the world adult population was $31.1 \%$ [3]. It is also known that the prevalence of hypertension is on the rise, not only in the adult [3], but also in the pediatric population [4]. However, research has shown that, in some countries, the average value of blood pressure over time decreases, which is an indication of the pharmacotherapy practice development in these countries. Such data have been recorded in countries like Norway [5], Finland [6], and Denmark [7]. The research carried out in Serbia has demonstrated that the prevalence of hypertension is significantly higher than the world average, and it is estimated at around $47 \%$ [8], while mortality rates for diseases caused by hypertension have risen by $113.6 \%$, in the period between 2009 and 2018 [9].

The main goal of pharmacotherapy for hypertension is to avoid its risks while maintaining a normal quality of life. The European Society of Hypertension (ESH) and The European Society of Cardiology (ESC) recommend, as drugs of first choice when starting medicamentous therapy in treating hypertension $[10,11]$, the following groups of medicaments: diuretics, beta-adrenergic blockers, calcium channel blockers, angiotensin-converting enzyme inhibitors (ACE inhibitors), and angiotensin II receptor blockers. However, 
kanala, inhibitore angiotenzin konvertujućeg enzima (ACE inhibitore), i blokatore angiotenzin II receptora. Međutim, prema dosadašnjem iskustvu, utvrđeno je da kod najmanje 75\% pacijenata sa dijagnozom hipertenzije, postoji potreba za kombinovanjem antihipertenzivnih lekova, jer se monoterapijom ne mogu postići dovoljno dobri rezultati [12]. Kod određenog broja bolesnika, regulisanje hipertenzije se može postići kombinovanjem antihipertenziva - primenom dva leka istovremeno ili primenom fiksne kombinacije dve lekovite supstance u jednom doziranom obliku.

Prema savremenim vodičima ESH/ESC, primarne kombinacije antihipertenziva su $[10,11]$ :

- Diuretik + ACE inhibitor

- Diuretik + blokator angiotenzinskih receptora

- Diuretik + antagonist kalcijuma

- ACE inhibitor + antagonist kalcijuma

- Blokator angiotenzinskih receptora + antagonist kalcijuma

Rezultat ovakvog pristupa lečenju hipertenzije jeste manji broj neželjenih reakcija na lekove, što je posledica nižih doza lekova u fiksnoj kombinaciji u odnosu na situaciju kada se daju pune doze lekova u monoterapiji. Stoga se može očekivati da će primena fiksnih kombinacija antihipertenziva dovesti do većeg sniženja krvnog pritiska i njegove bolje kontrole u odnosu na zasebno uzimanje antihipertenziva. Prednost fiksnih kombinacija je u jednostavnijem doziranju, boljoj komplijansi i teorijski nižoj ceni u odnosu na zbir pojedinačnih cena lekova koje čine kombinaciju $[10,11]$.

Ispitivanje potrošnje ACE inhibitora u Srbiji i Norveškoj, tokom 2009. i 2010. godine, pokazalo je postojanje razlike u količini i strukturi korišćenih lekova iz ove grupe, između analiziranih zemalja. Za razliku od Norveške, gde je upotreba lekova prvog izbora za lečenje hipertenzije bila ujednačena, u Srbiji je bila dominantna potrošnja $A C E$ inhibitora. Razlike u strukturi korišćenih ACE inhibitora odnosile su se na korišćenje skupljih lekova u Srbiji nego u Norveškoj, kako monokomponentnih, tako i njihovih kombinacija sa diureticima [13]. Studija koja je analizirala prepisivanje antihipertenzivnih lekova u Novom Sadu, tokom šestomesečnog perioda, 2011. i 2012. godine, takođe je pokazala neujednačenu zastupljenost lekova prvog izbora, kao i razlike u odnosu na prakse koje postoje u nordijskim zemljama (Finska i Norveška) [14]. Utvrđene razlike upućuju na potrebu za daljom analizom potrošnje ove grupe lekova u Srbiji, kao i za daljim poređenjem sa zemljama koje imaju dobro razvijenu farmakoterapijsku praksu, posebno ako se uzmu u obzir prevalenca i rizici koje hipertenzija nosi. according to the experience up to date, it has been established that in at least $75 \%$ of patients with a hypertension diagnosis there is a need for combining antihypertensive drugs, since monotherapy does not achieve satisfactory results [12]. In a certain number of patients, the regulation of hypertension can be achieved by combining antihypertensive drugs - by using two medicines at the same time or by applying a fixed combination of two drugs in single dosage form.

According to the current ESH/ESC guidelines, the primary combinations of antihypertensive drugs are $[10,11]$ :

- Diuretic + ACE inhibitor

- Diuretic + angiotensin receptor blocker

- Diuretic + calcium antagonist

- ACE inhibitor + calcium antagonist

- Angiotensin receptor blocker + calcium antagonist

The result of this approach to hypertension treatment is a reduced number of adverse reactions to drugs, which is the consequence of a lower drug dosage in the fixed combination as compared to the situation when full doses of drugs are given in monotherapy. Thus, it can be expected that the application of fixed antihypertensive drug combinations will bring about a more significant lowering of blood pressure and its better control, as compared to the application of separate antihypertensive drugs. The advantage of fixed drug combinations lies in simpler drug dosing, a better compliance, and in a theoretically lower price, when compared to the sum of the costs of the individual drugs that make up the combination $[10,11]$.

Research into the consumption of ACE inhibitors in Serbia and Norway, during 2009 and 2010, has shown a difference, between the analyzed countries, in the quantity and structure of the drugs applied from this group. As opposed to Norway, where the application of drugs of first choice for hypertension treatment was balanced, in Serbia, the consumption of ACE inhibitors was dominant. The differences in the structure of applied ACE inhibitors related to the application of more expensive drugs in Serbia than in Norway, both monocomponent drugs, and their combinations with diuretics [13]. A study analyzing the prescribing of antihypertensive drugs in Novi Sad, during a six-month period in 2011 and 2012, also demonstrated an uneven proportion of drugs of first choice, as well as differences to the practices that are in place in Nordic countries (Finland and Norway) [14]. The noted differences indicate the need for further analysis of the consumption of this group of drugs in Serbia, as well as the need for further comparison with countries which have a well-developed pharmacotherapy practice, especially when the prevalence and the risks that hypertension carries are taken into account. 
Cilj rada je bio da se analizira potrošnja fiksnih kombinacija iz podgrupe anatomsko-terapijsko-hemijskog (engl. Anatomical-Therapeutical-Chemical - ATC) sistema klasifikacije lekova C09 (lekovi koji deluju na renin-angiotenzin sistem - RAS) u Republici Srbiji, u periodu od 2010. do 2015. godine.

Takođe, cilj ispitivanja je bio da se dobijeni rezultati uporede sa potrošnjom istih lekova tokom istog vremenskog perioda u tri nordijske zemlje: Kraljevini Norveškoj, Republici Finskoj i Kraljevini Danskoj, zemljama koje imaju dobro razvijenu farmakoterapijsku praksu.

\section{MATERIJALI I METODE}

Podaci o potrošnji lekova u Republici Srbiji, za period od 2010. do 2015. godine, preuzeti su iz štampanih izdanja o godišnjoj potrošnji lekova, koje je izdala Agencija za lekove i medicinska sredstva Srbije (ALIMS) [15-20].

Podaci o potrošnji lekova u Kraljevini Norveškoj preuzeti su sa zvanične internet stranice Norveškog instituta za javno zdravlje - Folkehelseinstituttet [21].

Podaci o potrošnji lekova u Republici Finskoj preuzeti su sa zvanične internet stranice Finske Agencije za lekove - Fimea [22].

Podaci o potrošnji lekova u Kraljevini Danskoj preuzeti su sa zvanične internet stranice Danske Agencija za zaštitu podataka - Sundhedsdatastyrelsen [23].

Potrošnja lekova se izračunava metodologijom definisanih dnevnih doza (DDD), po ATC klasifikaciji, u skladu sa smernicama Svetske zdravstvene organizacije (SZO) za ispitivanje potrošnje lekova [24]. DDD predstavlja količinu aktivne supstance (prosečna doza) koja se u toku jednog dana koristi za lečenje glavne indikacije u odrasloj populaciji [25]. DDD je statistička jedinica mere upotrebe leka i ne zavisi od cene, oblika doziranja, veličine i pakovanja leka. Broj DDD/1.000 stanovnika/dan omogućava uvid u to koliki je broj stanovnika (od 1.000) koristio određeni lek i bio izložen njegovom delovanju u toku dana.

Rezultati o potrošnji fiksnih kombinacija lekova iz podgrupe C09 prikazani su tabelarno kao količina potrošenih lekova izražena kroz broj DDD/1.000 stanovnika/dan i kao procenat ukupne potrošnje ove podgrupe.

\section{REZULTATI}

Iz Tabele 1 vidi se da je potrošnja fiksnih kombinacija lekova iz ATC podgrupe C09 (C09B i C09D) u Srbiji, bila u porastu tokom posmatranog perioda, osim u 2013. i 2015. godini, kada je zabeležen blagi pad potrošnje fiksnih kombinacija $A C E$ inhibitora (C09B) u odnosu na
The aim of this study was to analyze the consumption of fixed combinations of drugs from the subgroup of the anatomical-therapeutic-chemical (ATC) system of the C09 drug classification (agents acting on the renin-angiotensin system - RAS), in the Republic of Serbia, in the period from 2010 to 2015.

Also, the aim was to compare the obtained results with the consumption of the same drugs in the Kingdom of Norway, the Republic of Finland, and the Kingdom of Denmark (countries with well-developed pharmacotherapy practices), in the same period.

\section{MATERIALS AND METHODS}

The data on drug consumption in the Republic of Serbia, in the period between the years 2010 and 2015, were taken from printed annual reports published by the Medicines and Medical Devices Agency of Serbia (ALIMS) [15-20].

The data on drug consumption in the Kingdom of Norway were taken from the official website of the Norwegian Institute of Public Health - Folkehelseinstituttet [21].

The data on drug consumption in the Republic of Finland were taken from the official website of the Finnish Drug Agency - Fimea [22].

The data on drug consumption in the Kingdom of Denmark were taken from the official website of the Danish Data Protection Agency - Sundhedsdatastirelsen [23].

The quantity of drugs consumed is calculated by means of the defined daily dose (DDD) methodology, according to the ATC classification, and in keeping with the World Health Organization (WHO) guidelines for drug utilization research [24]. DDD represents the quantity of the active ingredient (average dose) which is used in the adult population, in one day, to treat the main indication [25]. The DDD is a statistical unit of drug usage and does not depend on the cost, the dosage form, or size of the drug packaging. The number of DDD per 1,000 inhabitants per day (DDD/1,000 inhabitants/day) provides insight into the number of individuals in the population (per 1,000) who had used a certain drug and who had been exposed to its influence during the day.

The results on the consumption of fixed drug combinations from the $\mathrm{C} 09$ subgroup are shown in the tables as the quantity of drugs consumed, expressed as the number of DDD/1,000 inhabitants/day, and as the percentage of the entire consumption of this subgroup.

\section{RESULTS}

Table 1 shows that the consumption of fixed combinations of drugs from the ATC subgroup C09 (C09B and C09D) in Serbia was on the rise during the observation period, except in the years 2013 and 2015, when a mild decrease in fixed combinations of ACE inhibitors (C09B) was registered, as compared to the preceding years. In the 
Tabela 1. Prikaz potrošnje inhibitora angiotenzin konvertujućeg enzima, kombinacije (podgrupa C09B); i potrošnje antagonista receptora angiotenzina II, kombinacije (podgrupa C09D), u Srbiji, u periodu od 2010. do 2015. godine, izraženo brojem DDD/1.000 stanovnika/dan i procentima (\%) ukupne potrošnje u podgrupi $\mathrm{C} 09$
Table 1. Overview of the consumption of angiotensin-converting enzyme inhibitors, combinations (subgroup (09B); and the consumption of angiotensin II receptor antagonists, combinations (subgroup C09D), in Serbia, in the period $2010-2015$, presented as the number DDD/1,000 inhabitants/day and as the percentage (\%) of total consumption in the $\mathrm{C} 09$ group

\begin{tabular}{|c|c|c|c|c|c|c|c|c|c|c|c|c|}
\hline \multirow{3}{*}{$\begin{array}{c}\text { Zemlja/Country } \\
\text { Godina/Year } \\
\text { ATC group }\end{array}$} & \multicolumn{12}{|c|}{ Srbija / Serbia } \\
\hline & \multicolumn{2}{|c|}{2010} & \multicolumn{2}{|c|}{2011} & \multicolumn{2}{|c|}{2012} & \multicolumn{2}{|c|}{2013} & \multicolumn{2}{|c|}{2014} & \multicolumn{2}{|c|}{2015} \\
\hline & DDD & $\%$ & DDD & $\%$ & DDD & $\%$ & DDD & $\%$ & DDD & $\%$ & DDD & $\%$ \\
\hline $\operatorname{cog}$ & 196.80 & 100.00 & 229.19 & 100.00 & 263.14 & 100.00 & 293.73 & 100.00 & 279.57 & 100.00 & 351.15 & 100.00 \\
\hline CO9B & 27.36 & 13.90 & 43.35 & 18.91 & 56.90 & 21.62 & 55.97 & 19.05 & 66.57 & 23.81 & 64.98 & 18.51 \\
\hline CO9BA & 27.30 & 13.87 & 43.00 & 18.76 & 55.52 & 21.10 & 54.53 & 18.56 & 63.10 & 22.57 & 61.70 & 17.57 \\
\hline СО9ВА02 & 2.93 & 1.49 & 13.50 & 5.89 & 13.41 & 5.10 & 16.06 & 5.47 & 15.33 & 5.48 & 18.39 & 5.24 \\
\hline СО9ВА03 & 1.14 & 0.58 & 3.94 & 1.72 & 5.26 & 2.00 & 5.61 & 1.91 & 6.86 & 2.45 & 7.15 & 2.04 \\
\hline СО9ВАО4 & 0.01 & 0.01 & 0.07 & 0.03 & 0.64 & 0.24 & 0.80 & 0.27 & 1.23 & 0.44 & 1.60 & 0.45 \\
\hline С09ВА05 & 7.38 & 3.75 & 9.98 & 4.35 & 18.42 & 7.00 & 12.74 & 4.34 & 17.91 & 6.41 & 18.35 & 5.22 \\
\hline СО9ВА06 & 1.38 & 0.70 & 3.27 & 1.43 & 4.84 & 1.84 & 7.25 & 2.47 & 9.78 & 3.50 & 6.11 & 1.74 \\
\hline С09ВА08 & 5.77 & 2.93 & 1.05 & 0.46 & 2.89 & 1.10 & 1.41 & 0.48 & 1.77 & 0.63 & 1.77 & 0.50 \\
\hline С09BA09 & 8.70 & 4.42 & 11.21 & 4.89 & 10.06 & 3.82 & 10.67 & 3.63 & 10.22 & 3.65 & 8.35 & 2.38 \\
\hline CO9BB & 0.06 & 0.03 & 0.33 & 0.14 & 1.37 & 0.52 & 1.44 & 0.49 & 3.47 & 1.24 & 3.28 & 0.93 \\
\hline СО9ВВ02 & - & & - & - & - & - & - & 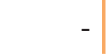 & - & - & - & - \\
\hline СО9ВВ03 & 0.02 & 0.01 & 0.07 & 0.03 & 0.49 & 0.19 & 0.80 & 0.27 & 1.13 & 0.41 & 1.60 & 0.46 \\
\hline С09ВВ04 & - & - & - & - & - & - & 0.64 & 0.22 & 1.19 & 0.42 & - & - \\
\hline С09ВВ05 & 0.04 & 0.02 & 0.26 & 0.11 & 0.88 & 0.33 & - & - & 1.15 & 0.41 & 1.68 & 0.48 \\
\hline CO9D & 0.20 & 0.10 & 0.75 & 0.33 & 1.72 & 0.65 & 2.10 & 0.71 & 3.43 & 1.23 & 5.76 & 1.64 \\
\hline CO9DA & 0.19 & 0.10 & 0.73 & 0.32 & 1.70 & 0.65 & 2.08 & 0.71 & 3.40 & 1.22 & 5.74 & 1.63 \\
\hline C09DA01 & 0.05 & 0.03 & 0.47 & 0.21 & 0.99 & 0.38 & 1.10 & 0.38 & 1.97 & 0.71 & 2.58 & 0.73 \\
\hline CO9DA02 & - & - & - & - & - & - & - & - & - & - & - & - \\
\hline C09DA03 & 0.13 & 0.07 & 0.21 & 0.09 & 0.54 & 0.21 & 0.73 & 0.25 & 1.25 & 0.45 & 2.35 & 0.67 \\
\hline C09DA04 & - & - & - & - & - & - & 0.09 & 0.03 & 0.18 & 0.06 & 0.47 & 0.13 \\
\hline CO9DA06 & - & - & - & - & 0.01 & 0.00 & 0.01 & 0.00 & 0.01 & 0.00 & 0.01 & 0.00 \\
\hline C09DA07 & 0.01 & 0.01 & 0.05 & 0.02 & 0.16 & 0.06 & 0.15 & 0.05 & 0.01 & 0.00 & 0.33 & 0.09 \\
\hline C09DA08 & - & - & - & - & - & - & - & - & - & - & - & - \\
\hline C09DB & 0.01 & 0.01 & 0.02 & 0.01 & 0.02 & 0.01 & 0.02 & 0.01 & 0.03 & 0.01 & 0.02 & 0.01 \\
\hline C09DB01 & 0.01 & 0.01 & 0.02 & 0.01 & 0.02 & 0.01 & 0.02 & 0.01 & 0.03 & 0.01 & 0.02 & 0.01 \\
\hline CO9DBO2 & - & - & - & - & - & - & - & - & - & - & - & - \\
\hline C09DX & - & - & - & - & - & - & - & - & - & - & - & - \\
\hline C09DX01 & - & - & - & - & - & - & - & - & - & - & - & - \\
\hline Other CO9 & 169.24 & 86.00 & 185.09 & 80.76 & 204.52 & 77.73 & 235.66 & 80.24 & 209.57 & 74.96 & 280.41 & 79.85 \\
\hline
\end{tabular}

C09- lekovi koji deluju na renin angiotenzin sistem

CO9B - inhibitori ACE, kombinacije

CO9BA - inhibitori ACE i diuretici

CO9BA02 - enalaprilihidrohlortiazid

COSBA03 - lizinoprili hidrohlortiazid

CO9BA04 - perindopriliindapamid

C09BA05 - ramiprilihidrohlortiazid

CO9BA06 - kvinaprilihidrohlortiazid

C09BA08 - cilazaprilihidrohlortiazid

C09BA09 - fosinoprilihidrohlortiazid

CO9BB -inhibitori ACE i blokatori kalcijumskih kanala
CO9BB02 - enalapril, lerkanidipin

CO9BB03 - lizinopril i amlodipin

CO9BB04 - perindopril i amlodipin

C09BB05 - felodipin i ramipril

CO9D - antagonisti receptora angiotenzina II, kombinacije

CO9DA - antagonisti receptora angiotenzina II i diuretici

C09DA01 - losartan i hidrohlortiazid

CO9DA02 - eprosartanihidrohlortiazid

CO9DA03 - valsartan i hidrohlortiazid

CO9DA04 - irbesartanihidrohlortiazid

CO9DA06 - kandesartanihidrohlortiazid
C09DA07 - telmisartan i hidrohlortiazid

C09DA08 - olmesartanihidrohlortiazid

CO9DB - antagonisti receptora angiotenzina II i blokatori kalcijumskih kanala

CO9DB01 - valsartaniamlodipin

CO9DB02 - olmesartaniamlodipin

CO9DX - antagonisti receptora angiotenzina II, druge kombinacije

CO9DX01 - valsartan, amlodipin i hidrohlorotiazid 
prethodnu godinu. Na prvom mestu nalazi se potrošnja kombinacije $A C E$ inhibitora i diuretika (C09BA), koja je 2010. godine iznosila 27,30 DDD/1.000 stanovnika/dan, ili 13,87\%, a 2015. godine 61,70 DDD/1.000 stanovnika/dan, ili 17,57\% ukupne potrošnje lekova u podgrupi C09. Najviše korišćena fiksna kombinacija u 2010. godini bila je fosinopril i hidrohlortiazid (C09BA09). Njena potrošnja u toj posmatranoj godini iznosila je 8,70 DDD/1.000 stanovnika/dan, ili 4,42\% ukupne potrošnje lekova u podgrupi C09, dok je njena potrošnja u 2015. godini iznosila 8,35 DDD/1.000 stanovnika/dan, ili 2,38\% ukupne potrošnje lekova u podgrupi C09. Kada su u pitanju fiksne kombinacije inhibitora $A C E$ i blokatora kalcijumskih kanala (C09BB), uočavamo da je njihova potrošnja u Srbiji neznatna.

U Tabeli 2 uočavamo da je potrošnja fiksnih kombinacija $A C E$ inhibitora (C09B) u Norveškoj u konstantnom padu. Na prvom mestu nalazi se potrošnja kombinacije $A C E$ inhibitora i diuretika (C09BA), koja je 2010. godine iznosila 6,51 DDD/1.000 stanovnika/ dan, ili 4,89\%, a 2015. godine 5,19 DDD/1.000 stanovnika/dan, ili 3,61\% ukupne potrošnje lekova u podgrupi C09. Dominirala je potrošnja fiksne kombinacije enalapril i hidrohlortiazid (C09BA02), koja je u 2010. godini iznosila 3,79 DDD/1.000 stanovnika/ dan, ili 2,85\% ukupne potrošnje lekova u podgrupi C09. Njena potrošnja u 2015. godini iznosila je 3,17 DDD/1.000 stanovnika/dan, ili 2,21\% ukupne potrošnje lekova u podgrupi C09. Kada su u pitanju fiksne kombinacije $A C E$ inhibitora i blokatora kalcijumskih kanala (C09BB) uočavamo da je njihova potrošnja u Norveškoj neznatna.

Potrošnja fiksnih kombinacija antagonista receptora angiotenzina II i diuretika (C09DA) u Norveškoj beleži dosta visoku vrednost, međutim takođe uočavamo i konstantan blagi pad potrošnje tokom posmatranog perioda. Najviše korišćena fiksna kombinacija jeste losartan i hidrohlortiazid (C09DA01), dok je odmah iza ove, fiksna kombinacija kandesartan i hidrohlortiazid (C09DA06). Primena kombinacije antagonista receptora angiotenzina II i blokatora kalcijumskih kanala (C09DB), u Norveškoj, tokom posmatranog perioda, beleži rast, te je 2010. godine iznosila 2,69 DDD/1.000 stanovnika/dan, ili 2,02\%, a 2015. godine je iznosila 4,37 DDD/1.000 stanovnika/dan, ili 3,04\% ukupne potrošnje lekova u podgrupi C09. Najviše korišćena fiksna kombinacija iz ove podgrupe lekova jeste valsartan i amlodipin (C09DB01).

Potrošnja fiksnih kombinacija $A C E$ inhibitora $\mathrm{u}$ Finskoj je u konstantnom padu (Tabela 3). Na prvom mestu nalazi se potrošnja kombinacije $A C E$ inhibitora i diuretika (C09BA), koja je 2010. godine iznosila 15,24 first place is the consumption of the combination of ACE inhibitors and diuretics (C09BA), which in 2010 amounted to $27.30 \mathrm{DDD} / 1,000$ inhabitants/day, or $13.87 \%$, and in 2015 it was 61.70 DDD/1,000 inhabitants/day, or $17.57 \%$ of the total consumption of drugs in the C09 subgroup. The most used fixed combination of drugs in 2010 was fosinopril with hydrochlorothiazide (C09BA09). Its consumption in that observed year amounted to $8.70 \mathrm{DDD} / 1,000$ inhabitants/day, or $4.42 \%$ of the total consumption of drugs in the C09 subgroup, while its consumption in year 2015 was $8.35 \mathrm{DDD} / 1,000$ inhabitants/day, or $2.38 \%$ of the total consumption of drugs in the C09 subgroup. As noted, the consumption of fixed combinations of ACE inhibitors and calcium channel blockers (C09BB) in Serbia is negligible.

Table 2 shows that the consumption of fixed combinations of ACE inhibitors (CO9B) in Norway is constantly decreasing. In the first place is the consumption of the combination of ACE inhibitors and diuretics (C09BA), which, in 2010, amounted to $6.51 \mathrm{DDD} / 1,000$ inhabitants/day, or $4.89 \%$, and in 2015 , it was $5.19 \mathrm{DDD} / 1,000$ inhabitants/day, or $3.61 \%$ of the total consumption of drugs in the C09 subgroup. The fixed combination of enalapril with hydrochlorothiazide (C09BA02) was dominantly consumed, and, in 2010, it amounted to 3.79 $\mathrm{DDD} / 1,000$ inhabitants/day, or $2.85 \%$ of the total consumption of drugs in the $\mathrm{C} 09$ subgroup. Its consumption in 2015 was $3.17 \mathrm{DDD} / 1,000$ inhabitants/day, or $2.21 \%$ of the total consumption of drugs in the C09 subgroup. As observed, the consumption of fixed combinations of ACE inhibitors with calcium channel blockers (C09BB) in Norway is negligible.

The consumption of fixed combinations of angiotensin II receptor antagonists with diuretics (C09DA) in Norway is quite high; however, it registered a constant mild decrease during the observation period. The most used fixed combination of drugs is losartan with hydrochlorothiazide (C09DA01), while the second most used fixed combination is candesartan with hydrochlorothiazide (C09DA06). The application of the combination of angiotensin II receptor antagonists with calcium channel blockers (C09DB) in Norway, during the observation period, registered a rise, and was $2.69 \mathrm{DDD} / 1,000$ inhabitants/day, or $2.02 \%$ in 2010 , while in 2015 it amounted to $4.37 \mathrm{DDD} / 1,000$ inhabitants/day, or $3.04 \%$ of the total consumption of drugs in the $\mathrm{CO} 9$ subgroup. The most applied fixed combination from this subgroup of drugs is valsartan with amlodipine (C09DB01).

The consumption of fixed combinations of ACE inhibitors in Finland is constantly decreasing (Table 3). In the first place is the consumption of the combination of ACE inhibitors and diuretics (C09BA), which, in 2010, amounted to $15.24 \mathrm{DDD} / 1,000$ inhabitants/day, or $7.45 \%$, and in 2015 it was 11.90 DDD/1,000 inhabitants/day, or 5.18\% 
Tabela 2. Prikaz potrošnje inhibitora angiotenzin konvertujućeg enzima, kombinacije (podgrupa C09B); i potrošnje antagonista receptora angiotenzina II, kombinacije (podgrupa C09D), u Norveškoj, u periodu od 2010. do 2015. godine, izraženo brojem DDD/1.000 stanovnika/dan i procentima (\%) ukupne potrošnje u podgrupi $\mathrm{CO}$
Table 2. Overview of the consumption of angiotensin-converting enzyme inhibitors, combinations (subgroup (09B); and the consumption of angiotensin II receptor antagonists, combinations (subgroup (09D), in Norway, in the period 2010 - 2015, presented as the number DDD/1,000 inhabitants/day and as the percentage (\%) of total consumption in the $\mathrm{C} 09$ group

\begin{tabular}{|c|c|c|c|c|c|c|c|c|c|c|c|c|}
\hline Zemlja/Country & & & & & & Vorveška & Norway & & & & & \\
\hline Godina/Year & 20 & & 20 & & 20 & & 20 & & 20 & & 20 & \\
\hline ATC group & DDD & $\%$ & DDD & $\%$ & DDD & $\%$ & DDD & $\%$ & DDD & $\%$ & DDD & $\%$ \\
\hline CO9 & 133.05 & 100.00 & 136.01 & 100.00 & 139.41 & 100.00 & 141.29 & 100.00 & 142.42 & 100.00 & 143.76 & 100.00 \\
\hline CO9B & 6.63 & 4.98 & 6.46 & 4.75 & 6.33 & 4.54 & 6.21 & 4.40 & 5.77 & 4.05 & 5.47 & 3.80 \\
\hline СО9BA & 6.51 & 4.89 & 6.25 & 4.60 & 6.08 & 4.36 & 5.94 & 4.20 & 5.49 & 3.85 & 5.19 & 3.61 \\
\hline СО9ВАО2 & 3.79 & 2.85 & 3.65 & 2.68 & 3.67 & 2.63 & 3.48 & 2.46 & 3.33 & 2.34 & 3.17 & 2.21 \\
\hline СО9ВА03 & 2.72 & 2.04 & 2.60 & 1.91 & 2.41 & 1.73 & 2.47 & 1.75 & 2.16 & 1.52 & 2.02 & 1.41 \\
\hline СО9BA04 & - & - & - & - & - & - & - & - & - & - & - & - \\
\hline CO9BA05 & - & - & - & - & - & - & - & - & - & - & - & - \\
\hline С09BA06 & - & - & - & - & - & - & - & - & - & - & - & - \\
\hline С09ВА08 & - & - & - & - & - & - & - & - & - & - & - & - \\
\hline С09ВА09 & - & - & - & - & - & - & - & - & - & - & - & - \\
\hline СО9BВ & 0.12 & 0.09 & 0.20 & 0.15 & 0.25 & 0.18 & 0.27 & 0.19 & 0.28 & 0.20 & 0.29 & 0.20 \\
\hline СО9ВВ02 & 0.12 & 0.09 & 0.20 & 0.15 & 0.25 & 0.18 & 0.27 & 0.19 & 0.28 & 0.20 & 0.29 & 0.20 \\
\hline СО9ВВ03 & & - & - & - & - & - & - & - & - & - & - & - \\
\hline СО9ВВ04 & - & - & - & - & - & - & - & - & - & - & - & - \\
\hline С09BВ05 & - & - & - & - & - & - & - & - & - & - & - & - \\
\hline CO9D & 36.92 & 27.75 & 37.91 & 27.87 & 39.06 & 28.02 & 39.67 & 28.08 & 39.90 & 28.02 & 39.68 & 27.60 \\
\hline C09DA & 33.72 & 25.34 & 33.48 & 24.62 & 33.64 & 24.13 & 33.10 & 23.43 & 32.51 & 22.83 & 31.74 & 22.08 \\
\hline CO9DA01 & 12.50 & 9.39 & 12.40 & 9.12 & 12.29 & 8.82 & 12.25 & 8.67 & 11.87 & 8.33 & 11.47 & 7.98 \\
\hline C09DA02 & 0.35 & 0.26 & 0.32 & 0.24 & 0.29 & 0.21 & 0.27 & 0.19 & 0.25 & 0.18 & 0.22 & 0.15 \\
\hline C09DA03 & 4.81 & 3.62 & 4.67 & 3.43 & 4.89 & 3.51 & 4.83 & 3.42 & 4.77 & 3.35 & 4.76 & 3.31 \\
\hline C09DA04 & 5.78 & 4.34 & 5.59 & 4.11 & 5.45 & 3.91 & 4.96 & 3.51 & 4.68 & 3.29 & 4.45 & 3.10 \\
\hline C09DA06 & 9.39 & 7.06 & 9.62 & 7.07 & 9.82 & 7.04 & 9.95 & 7.04 & 10.06 & 7.06 & 10.02 & 6.97 \\
\hline C09DA07 & 0.69 & 0.52 & 0.68 & 0.50 & 0.69 & 0.49 & 0.65 & 0.46 & 0.68 & 0.48 & 0.63 & 0.44 \\
\hline C09DA08 & 0.20 & 0.15 & 0.21 & 0.15 & 0.20 & 0.14 & 0.19 & 0.13 & 0.19 & 0.13 & 0.19 & 0.13 \\
\hline CO9DB & 2.69 & 2.02 & 3.10 & 2.28 & 3.48 & 2.50 & 3.88 & 2.75 & 4.18 & 2.93 & 4.37 & 3.04 \\
\hline C09DB01 & 2.69 & 2.02 & 3.07 & 2.26 & 3.43 & 2.46 & 3.83 & 2.71 & 4.13 & 2.90 & 4.32 & 3.01 \\
\hline C09DBO2 & & _ & 0.03 & 0.02 & 0.05 & 0.04 & 0.05 & 0.04 & 0.05 & 0.04 & 0.06 & 0.04 \\
\hline CO9DX & 0.51 & 0.38 & 1.33 & 0.98 & 1.95 & 1.40 & 2.69 & 1.90 & 3.21 & 2.25 & 3.56 & 2.48 \\
\hline C09DX01 & 0.51 & 0.38 & 1.33 & 0.98 & 1.95 & 1.40 & 2.69 & 1.90 & 3.21 & 2.25 & 3.56 & 2.48 \\
\hline Other C09 & 89.50 & 67.27 & 91.64 & 67.38 & 94.02 & 67.44 & 95.41 & 67.52 & 96.75 & 67.93 & 98.61 & 68.60 \\
\hline
\end{tabular}

C09-drugs acting on the renin-angiotensin system

CO9B - ACE inhibitors, combinations

CO9BA - ACE inhibitors with diuretics

CO9BA02 - enalapril with hydrochlorothiazide

CO9BA03 - lisinopril with hydrochlorothiazide

CO9BA04 - perindopril with indapamide

CO9BA05 - ramipril with hydrochlorothiazide

C09BA06 - quinapril with hydrochlorothiazide

CO9BA08 - cilazapril with hydrochlorothiazide

C09BA09 - fosinopril with hydrochlorothiazide

CO9BB - ACE inhibitors with calcium channel blockers
CO9BB02 - enalapril, lercanidipinie

CO9BB03 - lisinopril with amlodipine

CO9BB04 - perindopril with amlodipine

C09BB05 - felodipine with ramipril

CO9D - angiotensin II receptor antagonists, combinations

CO9DA - angiotensin II receptor antagonists with diuretics

CO9DA01 - losartan with hydrochlorothiazide

CO9DA02 - eprosartan with hydrochlorothiazide

CO9DA03 - valsartan with hydrochlorothiazide

CO9DA04 - irbesartan with hydrochlorothiazide

CO9DA06 - candesartan with hydrochlorothiazide
C09DA07 - telmisartan with hydrochlorothiazide

C09DA08 - olmesartan with hydrochlorothiazide

CO9DB - angiotensin II receptor antagonists with calcium channel blockers

C09DB01 - valsartan with amlodipine

CO9DB02 - olmesartan with amlodipine

COSDX - angiotensin II receptor antagonists, other combinations

C09DX01 - valsartan, amlodipine and hydrochlorothiazide 
Tabela 3. Prikaz potrošnje inhibitora angiotenzin konvertujućeg enzima, kombinacije (podgrupa C09B); i potrošnje antagonista receptora angiotenzina II, kombinacije (podgrupa C09D), u Finskoj, u periodu od 2010. do 2015. godine, izraženo brojem DDD/1.000 stanovnika/dan i procentima (\%) ukupne potrošnje u podgrupi $\mathrm{C} 09$
Table 3. Overview of the consumption of angiotensin-converting enzyme inhibitors, combinations (subgroup (09B); and the consumption of angiotensin II receptor antagonists, combinations (subgroup (09D), in Finland, in the period 2010 - 2015, presented as the number DDD/1,000 inhabitants/day and as the percentage (\%) of total consumption in the $\mathrm{C} 09$ group




Tabela 4. Prikaz potrošnje inhibitora angiotenzin konvertujućeg enzima, kombinacije (podgrupa C09B); i potrošnje antagonista receptora angiotenzina II, kombinacije (podgrupa C09D), u Danskoj, u periodu od 2010. do 2015. godine, izraženo brojem DDD/1.000 stanovnika/dan i procentima (\%) ukupne potrošnje u podgrupi $\mathrm{CO}$
Table 4. Overview of the consumption of angiotensin-converting enzyme inhibitors, combinations (subgroup (09B); and the consumption of angiotensin II receptor antagonists, combinations (subgroup (09D), in Denmark, in the period 2010 - 2015, presented as the number DDD/1,000 inhabitants/day and as the percentage (\%) of total consumption in the $\mathrm{C} 09$ group

\begin{tabular}{|c|c|c|c|c|c|c|c|c|c|c|c|c|}
\hline Zemlja/Country & & & & & & Danska / & enmark & & & & & \\
\hline Godina/Year & 20 & & 20 & & 20 & & 20 & & 20 & & 20 & \\
\hline ATC group & DDD & $\%$ & DDD & $\%$ & DDD & $\%$ & DDD & $\%$ & DDD & $\%$ & DDD & $\%$ \\
\hline CO9 & 160.50 & 100.00 & 164.90 & 100.00 & 171.60 & 100.00 & 174.30 & 100.00 & 175.70 & 100.00 & 177.50 & 100.00 \\
\hline CO9B & 19.20 & 11.96 & 19.60 & 11.89 & 19.60 & 11.42 & 19.00 & 10.90 & 18.20 & 10.36 & 17.60 & 9.92 \\
\hline СО9BA & 19.20 & 11.96 & 19.60 & 11.89 & 19.60 & 11.42 & 19.00 & 10.90 & 18.20 & 10.36 & 17.60 & 9.92 \\
\hline СО9ВАО2 & 12.90 & 8.04 & 13.20 & 8.00 & 13.30 & 7.75 & 13.10 & 7.52 & 12.70 & 7.23 & 12.30 & 6.93 \\
\hline С09BA03 & 1.80 & 1.12 & 1.90 & 1.15 & 1.90 & 1.11 & 1.70 & 0.98 & 1.50 & 0.85 & 1.40 & 0.79 \\
\hline С09BA04 & 0.30 & 0.19 & 0.20 & 0.12 & 0.20 & 0.12 & 0.10 & 0.06 & 0.10 & 0.06 & 0.10 & 0.06 \\
\hline CO9BA05 & 4.20 & 2.62 & 4.30 & 2.61 & 4.20 & 2.45 & 4.10 & 2.35 & 3.90 & 2.22 & 3.80 & 2.14 \\
\hline С09BA06 & - & - & - & - & - & - & - & - & - & - & - & - \\
\hline С09ВА08 & - & - & - & - & - & - & - & - & - & - & - & - \\
\hline С09ВА09 & - & - & - & - & - & - & - & - & - & - & - & - \\
\hline CO9BВ & - & - & - & - & - & - & - & - & - & - & - & - \\
\hline СО9ВВ02 & - & - & - & - & - & - & - & - & - & - & - & - \\
\hline СО9ВВ03 & - & - & - & - & - & - & - & - & - & - & - & - \\
\hline СО9ВВ04 & - & - & - & - & - & - & - & - & - & - & - & - \\
\hline С09BВ05 & - & - & - & - & - & - & - & - & - & - & - & - \\
\hline CO9D & 17.30 & 10.78 & 18.70 & 11.34 & 20.70 & 12.06 & 21.80 & 12.51 & 22.70 & 12.92 & 23.20 & 13.07 \\
\hline C09DA & 16.40 & 10.22 & 18.60 & 11.28 & 20.60 & 12.00 & 21.70 & 12.45 & 22.70 & 12.92 & 23.20 & 13.07 \\
\hline C09DA01 & 9.20 & 5.73 & 17.70 & 10.73 & 19.90 & 11.60 & 21.10 & 12.11 & 21.90 & 12.46 & 22.30 & 12.56 \\
\hline C09DA02 & 0.20 & 0.12 & - & - & - & - & - & - & - & - & - & - \\
\hline C09DA03 & 2.00 & 1.25 & 0.20 & 0.12 & 0.20 & 0.12 & 0.20 & 0.11 & 0.20 & 0.11 & 0.20 & 0.11 \\
\hline C09DA04 & 1.40 & 0.87 & 0.20 & 0.12 & 0.10 & 0.06 & 0.10 & 0.06 & 0.10 & 0.06 & 0.10 & 0.06 \\
\hline C09DA06 & 2.30 & 1.43 & 0.30 & 0.18 & 0.30 & 0.17 & 0.30 & 0.17 & 0.30 & 0.17 & 0.40 & 0.23 \\
\hline C09DA07 & 1.10 & 0.69 & 0.20 & 0.12 & 0.10 & 0.06 & 0.10 & 0.06 & 0.20 & 0.11 & 0.20 & 0.11 \\
\hline C09DA08 & 0.20 & 0.12 & - & - & - & - & - & - & - & - & - & - \\
\hline C09DB & 0.80 & 0.50 & 0.10 & 0.06 & 0.10 & 0.06 & - & - & - & - & - & - \\
\hline C09DB01 & 0.80 & 0.50 & 0.10 & 0.06 & 0.10 & 0.06 & - & - & - & - & - & - \\
\hline C09DBO2 & & - & - & - & - & - & - & - & - & - & - & - \\
\hline CO9DX & 0.10 & 0.06 & - & - & - & - & - & - & - & - & - & - \\
\hline C09DX01 & 0.10 & 0.06 & - & & - & - & - & - & - & - & - & - \\
\hline Other Co9 & 124.00 & 77.26 & 126.60 & 76.77 & 131.30 & 76.52 & 133.50 & 76.59 & 134.80 & 76.72 & 136.70 & 77.01 \\
\hline
\end{tabular}

C09-drugs acting on the renin-angiotensin system

CO9B - ACE inhibitors, combinations

CO9BA - ACE inhibitors with diuretics

CO9BA02 - enalapril with hydrochlorothiazide

CO9BA03 - lisinopril with hydrochlorothiazide

CO9BA04 - perindopril with indapamide

CO9BA05 - ramipril with hydrochlorothiazide

CO9BA06 - quinapril with hydrochlorothiazide

CO9BA08 - cilazapril with hydrochlorothiazide

C09BA09 - fosinopril with hydrochlorothiazide

CO9BB - ACE inhibitors with calcium channel blockers
CO9BB02 - enalapril, lercanidipinie

C09BB03 - lisinopril with amlodipine

CO9BB04 - perindopril with amlodipine

C09BB05 - felodipine with ramipril

CO9D - angiotensin II receptor antagonists, combinations

CO9DA - angiotensin II receptor antagonists with diuretics

C09DA01 - losartan with hydrochlorothiazide

CO9DA02 - eprosartan with hydrochlorothiazide

CO9DA03 - valsartan with hydrochlorothiazide

CO9DA04 - irbesartan with hydrochlorothiazide

CO9DA06 - candesartan with hydrochlorothiazide
C09DA07 - telmisartan with hydrochlorothiazide

C09DA08 - olmesartan with hydrochlorothiazide

CO9DB - angiotensin II receptor antagonists with calcium channel blockers

C09DB01 - valsartan with amlodipine

CO9DB02 - olmesartan with amlodipine

CO9DX - angiotensin II receptor antagonists, other combinations

CO9DX01 - valsartan amlodipine and hydrochlorothiazide 
DDD/1.000 stanovnika/dan, ili 7,45\%, a 2015. godine 11,90 DDD/1.000 stanovnika/dan, ili 5,18\% ukupne potrošnje lekova u podgrupi C09; pri čemu je dominirala potrošnja fiksne kombinacije enalapril i hidrohlortiazid (C09BA02). Potrošnja fiksnih kombinacija ACE inhibitora i blokatora kalcijumskih kanala (C09BB) je bila prilično niska, ali konstantna, tokom posmatranog šestogodišnjeg perioda.

Potrošnja fiksnih kombinacija antagonista receptora angiotenzina II i diuretika (C09DA) u Finskoj beleži dosta visoku i relativno konstantnu vrednost. U 2010. godini, potrošnja fiksnih kombinacija antagonista receptora angiotenzina II i diuretika (C09DA) u Finskoj je iznosila 26,18 DDD/1.000 stanovnika/dan, ili 12,80\% ukupne potrošnje lekova u podgrupi C09, dok je u 2015. godine iznosila 27,56 DDD/1.000 stanovnika/ dan, ili 11,99\% ukupne potrošnje lekova u podgrupi C09. Slično kao i u Norveškoj, i u Finskoj je najviše korišćena fiksna kombinacija losartan i hidrohlortiazid (C09DA01), dok je odmah iza ove fiksna kombinacija kandesartan i hidrohlortiazid (C09DA06).

Od fiksnih kombinacija ACE inhibitora, tokom posmatranog perioda, u Danskoj potrošnju beleže fiksne kombinacije ACE inhibitora i diuretika (C09BA). U 2010. godini, potrošnja lekova iz ove podgrupe iznosila je 19,20 DDD/1.000 stanovnika/dan, ili 11,96\%, a 2015. godine je bila 17,60 DDD/1.000 stanovnika/ dan, ili 9,92\% ukupne potrošnje lekova u podgrupi C09. Trend pada potrošnje ove kombinacije postojao je u svakoj posmatranoj godini. Dominirala je potrošnja fiksne kombinacije enalapril i hidrohlortiazid (C09BA02), koja je u 2010. godini iznosila 12,90 DDD/1.000 stanovnika/dan, ili 8,04\% ukupne potrošnje lekova u podgrupi C09. Potrošnja ove fiksne kombinacije je u 2015. godini iznosila 12,30 DDD/1.000 stanovnika/dan, ili 6,93\% ukupne potrošnje lekova u podgrupi C09. Potrošnja fiksnih kombinacija inhibitora ACE i blokatora kalcijumskih kanala (C09BB) u Danskoj, u posmatranom periodu od šest godina, nije registrovana.

Potrošnja fiksnih kombinacija antagonista receptora angiotenzina II i diuretika (C09DA) u Danskoj beleži konstantan rast tokom posmatranog perioda. U 2010. godini, iznosila je 16,40 DDD/1.000 stanovnika/dan, ili 10,22\%, dok je u 2015. godini iznosila 23,20 DDD/1.000 stanovnika/dan, ili 13,07\% ukupne potrošnje lekova u podgrupi C09. Dominirala je potrošnja fiksne kombinacije losartan i hidrohlortiazid (C09DA01), a sve ostale fiksne kombinacije iz ove podgrupe lekova su izuzetno malo korišćene. of the total consumption of drugs in the C09 subgroup; with the dominant consumption being that of the fixed combination of enalapril with hydrochlorothiazide (C09BA02). The consumption of fixed combinations of ACE inhibitors with calcium channel blockers (C09BB) was quite low, but constant, during the six-year observation period.

The consumption of fixed combinations of angiotensin II receptor antagonists with diuretics (C09DA) in Finland is quite high and relatively constant. In 2010, the consumption of fixed combinations of angiotensin II receptor antagonists with diuretics (C09DA), in Finland, amounted to $26.18 \mathrm{DDD} / 1,000$ inhabitants/day, or $12.80 \%$ of the total consumption of drugs in the C09 subgroup; while in 2015 it was $27.56 \mathrm{DDD} / 1,000$ inhabitants/day, or $11.99 \%$ of the total consumption of drugs in the C09 subgroup. Similarly to Norway, the fixed combination of losartan with hydrochlorothiazide (C09DA01) was the most consumed one in Finland, while the second most consumed fixed combination of drugs was candesartan with hydrochlorothiazide (C09DA06).

Of all the fixed combinations of ACE inhibitors, during the observation period, in Denmark, consumption was registered for the fixed combinations of ACE inhibitors with diuretics (C09BA). In 2010, the consumption of drugs from this subgroup amounted to 19.20 $\mathrm{DDD} / 1,000$ inhabitants/day, or $11.96 \%$, and in 2015 it was $17.60 \mathrm{DDD} / 1,000$ inhabitants/day, or $9.92 \%$ of the total consumption of drugs in the C09 subgroup. The trend of a decrease in the consumption of this drug combination was registered in each of the observed years. The consumption of the fixed combination of enalapril with hydrochlorothiazide (CO9BA02) was dominant, and in 2010 it amounted to $12.9 \mathrm{DDD} / 1,000$ inhabitants/day, or $8.04 \%$ of the total consumption of drugs in the C09 subgroup. The consumption of this fixed drug combination in 2015 was 12.3 DDD/1,000 inhabitants/day, or $6.93 \%$ of the total consumption of drugs in the C09 subgroup. The consumption of fixed combinations of ACE inhibitors with calcium channel blockers (C09BB) in Denmark was not registered in the six-year observation period.

The consumption of fixed combinations of angiotensin II receptor antagonists with diuretics (C09DA) in Denmark showed a constant increase throughout the observation period. In 2010 it amounted to 16.40 DDD/1,000 inhabitants/day, or $10.22 \%$, while in 2015 it was $23.20 \mathrm{DDD} / 1,000$ inhabitants/day, or $13.07 \%$ of the total consumption of drugs in the C09 subgroup. The consumption of the fixed combination of losartan with hydrochlorothiazide (CO9DA01) was dominant, while all other fixed combinations of drugs from this subgroup were used in a very small quantity. 


\section{DISKUSIJA}

Na osnovu dobijenih rezultata, u posmatranom periodu, u Srbiji, uočava se porast potrošnje fiksnih kombinacija ACE inhibitora i diuretika (CO9BA) sa oko 14\%, u 2010. godini, na oko $18 \%$ ukupne potrošnje lekova iz podgrupe C09, u 2015. godini. U nordijskim zemljama potrošnja fiksnih kombinacija $A C E$ inhibitora i diuretika je manja nego u Srbiji i vremenom opada. Njihova potrošnja u Norveškoj, u 2010. godini, iznosila je oko 5\%, a u 2015. godini, ispod 4\%; u Finskoj je bila nešto veća, i u 2010. godini je iznosila oko 7\%, a u 2015. godini oko 5\%; dok je u Danskoj, u 2010. godini, iznosila oko $12 \%$, a u 2015 . godini oko $10 \%$ ukupne potrošnje lekova iz podgrupe C09. U sve četiri zemlje, na prvom mestu po potrošnji se nalazi kombinacija enalaprila i hidrohlortiazida. U Srbiji, značajno učešće u potrošnji ima i kombinacija ramiprila i hidrohlortiazida, koja ne beleži potrošnju u Norveškoj, dok u Finskoj i Danskoj beleži potrošnju, ali značajno manje nego fiksna kombinacija enalapril i hidrohlortiazid.

Fiksne kombinacije lekova su od velikog značaja u lečenju arterijske hipertenzije. $U$ većini istraživanja kombinacija dva ili više leka bila je neophodna da bi se postigla regulacija krvnog pritiska $[11,12,26]$. Kombinacije dva leka u jednom doziranom obliku su danas uveliko dostupne, posebno kombinacije antagonista angiotenzinskih receptora sa tiazidnim diureticima; kombinacije $A C E$ inhibitora sa tiazidnim diureticima ili antagonistima kalcijumskih kanala; kao i kombinacije beta blokatora sa diureticima, i tiazida sa diureticima koji štede kalijum [26]. Dostupnost pojedinih fiksnih kombinacija lekova u posmatranim zemljama može se videti u Tabelama 1-4.

Kombinacijom ACE inhibitora i diuretika (obično sa tiazidima) postiže se bolja kontrola hipertenzije onda kada sam ACE inhibitor nije dovoljno delotvoran, ili u slučajevima hroničnog srčanog zatajenja, kada se obično dodaje furosemid. Kombinacija $A C E$ inhibitora i diuretika je zanimljiva i u pogledu kalijuma, jer, iako diuretik (najčešće je to hidrohlortiazid) snižava nivo kalijuma u krvi, $A C E$ inhibitori dovode do povećanja nivoa kalijuma u krvi, pa ne dolazi do disbalansa kalijuma [27]. Studija Action in Diabetes and Vascular Disease: Preterax and Diamicron MR Controlled Evaluation (ADVANCE) govori u prilog uspešnosti fiksnih kombinacija lekova kod bolesnika s tipom 2 šećerne bolesti, gde je fiksna kombinacija $A C E$ inhibitora perindoprila i diuretika indapamida dovela do statistički značajno manjeg broja kardiovaskularnih i bubrežnih oboljenja [28].

Na srpskom tržištu prisutna je i kombinacija $A C E$ inhibitora i antagonista kalcijumskih kanala (C09BB),

\section{DISCUSSION}

Based on the results obtained, it is evident that, during the observation period, in Serbia, the consumption of the fixed combinations of ACE inhibitors and diuretics (C09BA) showed an increase from around 14\%, in 2010, to around $18 \%$ of the total consumption of drugs in the C09 subgroup, in year 2015. In Nordic countries, the consumption of fixed combinations of ACE inhibitors and diuretics is lesser than in Serbia, and is decreasing with time. In 2010, their consumption in Norway was around 5\%, while in 2015 it was less than 4\%; in Finland it was somewhat higher, and in 2010 it amounted to 7\%, while in 2015 it was around 5\%; in Denmark, it was around $12 \%$ in 2010 , and in 2015, it was around $10 \%$ of the total consumption of drugs in the C09 subgroup. In all four countries, the first place, as to consumption, belongs to the combination of enalapril with hydrochlorothiazide. In Serbia, the combination of ramipril with hydrochlorothiazide makes up a significant portion of consumption, while it shows no consumption in Norway, and in Finland and Denmark, consumption is registered, but it is significantly lower than the fixed combination of enalapril with hydrochlorothiazide.

Fixed combinations of drugs are very important in arterial hypertension treatment. Most studies show that a combination of two or more medications is necessary in order to achieve blood pressure regulation $[11,12,26]$. Combinations of two drugs in a single dosage form are widely available today, especially combinations of angiotensin receptor antagonists with thiazide diuretics; combinations of ACE inhibitors with thiazide diuretics or calcium channel antagonists; as well as combinations of beta blockers with diuretics, and thiazides with potassium-sparing diuretics [26]. The availability of individual fixed drug combinations in the observed countries is shown in Tables 1-4.

By combining ACE inhibitors with diuretics (usually thiazides) a better control of hypertension is achieved, in cases where the ACE inhibitor itself is not sufficiently effective, or in cases of chronic heart failure, when furosemide is usually added. The combination of ACE inhibitors with diuretics is also interesting in relation to potassium, since, although the diuretic (usually it is hydrochlorothiazide) lowers the potassium level in the blood, ACE inhibitors elevate the potassium level, so an imbalance in potassium does not occur [27]. The Action in Diabetes and Vascular Disease: Preterax and Diamicron MR Controlled Evaluation (ADVANCE) study speaks in favor of the effectiveness of fixed combinations of drugs in patients with type 2 diabetes, where the fixed combination of the ACE inhibitor perindopril with the diuretic indapamide has brought about a statistically significant decrease in the number of cardiovascular and renal diseases [28]. The combination of 
ali je njena potrošnja u sve četiri posmatrane zemlje mala. ACE inhibitori i antagonisti kalcijumskih kanala osiguravaju dugotrajan i povoljan efekat na kardiovaskularne komplikacije povezane sa arterijskom hipertenzijom. Njihov mehanizam delovanja na srce, krvne sudove i bubrege sinergičan je u snižavanju krvnog pritiska, uz dobru podnošljivost i nizak procenat neželjenih reakcija na lekove. Pokazano je da ova kombinacija poboljšava izglede preživljavanja kod srčane insuficijencije [29].

Antagonisti receptora za angiotenzin II takođe deluju na RAS, ali drugačijim mehanizmom u odnosu na $A C E$ inhibitore. Oni izazivaju manje neželjenih reakcija na lekove zato što ne dovode da povećanja bradikinina, pa se koriste kao zamena za ACE inhibitore [27].

Prema našim rezultatima, Srbija, u odnosu na analizirane nordijske zemlje, najmanje troši kombinacije antagonista angiotenzina II. Potrošnja fiksnih kombinacija antagonista receptora angiotenzina II sa diureticima u Srbiji je veoma mala i iznosi tek oko 1\% ukupne potrošnje lekova koji deluju na RAS. Potrošnja ove kombinacije lekova u Norveškoj beleži blagi pad, i bila je preko 25 puta veća u 2010. godini, odnosno preko 22 puta veća u 2015. godini nego u Srbiji. U Finskoj, ova fiksna kombinacija ima konstantnu potrošnju, te je u posmatranom periodu bila oko 14 puta veća nego u Srbiji. Potrošnja ove fiksne kombinacije u Danskoj beleži blagi rast i bila je više od 10 puta veća u 2010. godini, odnosno više od 13 puta veća u 2015. godini nego u Srbiji.

Blokatori angiotenzinskih receptora koriste se i kao fiksna kombinacija s blokatorima kalcijumskih kanala, a novija istraživanja su pokazala da kombinacija amlodipina sa valsartanom dovodi do značajnijeg sniženja krvnog pritiska u odnosu na pojedinačne monoterapijske komponente. Takođe je dokazana bolja tolerancija ove kombinacije u poređenju s monoterapijom [29]. Potrošnja ove fiksne kombinacije je jako mala u sve četiri posmatrane zemlje, u periodu od 2010. do 2015. godine. U Srbiji i Danskoj potrošnja ove fiksne kombinacije je skoro nemerljiva, dok u Norveškoj i Finskoj iznosi između 1\% i 3\% ukupne potrošnje lekova iz C09 podgrupe.

Studija koja je ispitivala potrošnju lekova među odraslom populacijom sa hipertenzijom u Sjedinjenim Američkim Državama (SAD), u periodu od 2001. do 2010. godine, obuhvatila je 9.320 pacijenata. Studija je pokazala da je u posmatranoj deceniji povećan procenat ljudi sa hipertenzijom koji su koristili lekove za kontrolu nivoa krvnog pritiska, a najveće povećanje se odnosilo na kombinovanu antihipertenzivnu terapiju. Kombinovana antihipertenzivna terapija je
ACE inhibitors and calcium channel antagonists (C09BB) is present on the Serbian market, though its consumption in all the observed countries is small. ACE inhibitors and calcium channel antagonists provide a long-term and beneficial effect on cardiovascular complications connected to arterial hypertension. The mechanism of their action on the heart, blood vessels, and the kidneys is synergistic in the lowering of blood pressure, with a good tolerance and a low percentage of adverse drug reactions. It has been demonstrated that this combination of drugs improves the survival outlook in cardiac insufficiency [29].

Angiotensin II receptor antagonists also act on the RAS but through a different mechanism than ACE inhibitors. They cause a lesser number of adverse drug reactions as they do not cause an increase in bradykinin, which is why they are used as ACE inhibitor replacements [27].

According to our results, in comparison to the analyzed Nordic countries, Serbia consumes the smallest quantity of angiotensin II receptor antagonist combinations. The consumption of fixed combinations of angiotensin II receptor antagonists with diuretics in Serbia is very small and amounts to only $1 \%$ of the total consumption of drugs acting on the RAS. The consumption of this drug combination in Norway registered a mild decrease and was over 25 times higher in 2010, i.e. over 22 times higher in 2015, than in Serbia. In Finland, the consumption of this fixed drug combination is constant, and, during the observation period, it was 14 times higher than in Serbia. The consumption of this fixed drug combination in Denmark registered a mild increase, and was more than 10 times higher in 2010, i.e. more than 13 times higher in 2015, than in Serbia.

Angiotensin receptor blockers are also used as a fixed combination with calcium channel blockers, and more recent research has shown that the combination of amlodipine with valsartan leads to a more significant decrease in blood pressure than individual components in monotherapy. Also, when compared to monotherapy, a better tolerance of this combination has been proven [29]. The consumption of this fixed drug combination, in the period between 2010 and 2015, was very small in all four countries observed. In Serbia and Denmark, the consumption of this fixed drug combination was almost impossible to measure, while in Norway and Finland, it was between $1 \%$ and $3 \%$ of the total consumption of drugs in the $\mathrm{C} 09$ subgroup.

A study examining drug consumption among the hypertensive adult population in the United States of America (USA), in the period between 2001 and 2010, involved 9,320 patients. The study showed that, in the observed decade, the proportion of people with hypertension using drugs for regulating blood pressure had increased, and that the greatest increase had been in 
bila efikasnija od monoterapije i podrazumevala je primenu više antihipertenzivnih lekova u jednom ili više doznih oblika. Kao i u nordijskim zemljama, i u SAD je upotreba pojedinih lekova prvog izbora za lečenje hipertenzije bila ujednačena [30]. Skorija studija, na sličnoj veličini uzorka, pokazala je ponovo veću upotrebu kombinovane terapije za regulisanje hipertenzije u SAD, u odnosu na monoterapiju, ali i veće troškove za pacijente koji su je koristili [31].

Istraživanje sprovedeno u susednoj Hrvatskoj pokazalo je da je došlo do promena u prepisivanju antihipertenzivnih lekova u periodu od 2000. do 2016. godine. Najviše korišćena grupa antihipertenziva, u svim posmatranim godinama, bili su oni lekovi koji deluju na RAS (C09), uz povećanje udela fiksnih kombinacija $A C E$ inhibitora sa diureticima u potrošnji. Najveći porast potrošnje lekova u posmatranom periodu se odnosio upravo na ove fiksne kombinacije i iznosio je čak $+856,58 \%$. I u Hrvatskoj, i u Srbiji, dominira potrošnja lekova iz ATC grupe C09 u odnosu na ostale lekove prvog izbora za lečenje hipertenzije. Ovo je posebno bilo vidljivo pri kraju opservacionog perioda [32].

Ovom studijom analizirani su samo podaci dostupni na engleskom i srpskom jeziku. Nije sprovedena analiza potencijalnih razlika u nacionalnim vodičima za lečenje hipertenzije u posmatranim zemljama.

\section{ZAKLJUČAK}

Rezultati ovog rada ukazuju na porast korišćenja lekova iz analizirane grupe (ATC grupa C09 - lekovi koji deluju na RAS), a pokazane razlike u vrsti korišćenih lekova između Srbije i nordijskih zemalja ukazuju na potrebu za usaglašavanjem prakse u Srbiji sa praksama u zemljama sa razvijenom farmakoterapijom. Buduća istraživanja bi trebalo da ispitaju ekonomsku isplativost $\mathrm{i}$ zdravstvene efekte ovakve potrošnje analiziranih lekova, sa ciljem da se dobijeni rezultati implementiraju u smernice za kliničku praksu.

Sukob interesa: Nije prijavljen.

\section{LITERATURA / REFERENCES}

1. Republička stručna komisija za izradu i implementaciju vodiča u kliničkoj praksi, Ministarstvo zdravlja Republike Srbije. Srpsko lekarsko društvo. Prevencija kardiovaskularnih bolesti - Nacionalni vodič za lekare u primarnoj zdravstvenoj zaštiti. 2005. [citirano 18.04.2020.]. Dostupno na: https:// www.zdravlje.gov.rs/view_file.php?file_id=700\&cache $=$ sr

2. Wilkins E, Wilson L, Wickramasinghe $K$, Bhatnagar P, Leal J, Luengo-Fernan$\operatorname{dez} \mathrm{R}$, et al. European cardiovascular disease statistics. 2017. the use of combined antihypertensive therapy. Combined antihypertensive therapy was more efficient than monotherapy, and it entailed the application of several antihypertensive drugs in a single or multi dosage form. Just like in the Nordic countries, the application of certain drugs of first choice for hypertension treatment, in USA, was also balanced [30]. A more recent study, on a sample of similar size, again showed a higher consumption of combined therapy for regulating hypertension in USA, as compared to monotherapy, but also a higher cost for the patients using this therapy [31].

A study carried out in neighboring Croatia shows that a change occurred in the prescribing of antihypertensive drugs, in the period between 2000 and 2016. The most prescribed group of antihypertensive drugs in all the observed years was the group of drugs acting on the RAS (C09), with an increase in the share of fixed combinations of ACE inhibitors with diuretics in the total consumption. The greatest increase in drug consumption during the observation period did, in fact, relate to these fixed combinations and was as much as $+856.58 \%$. In Croatia, just like in Serbia, the consumption of drugs from the C09 ATC group is dominant, in comparison with other drugs of first choice for hypertension treatment. This was especially evident at the end of the observation period [32].

This study analyzes only the data available in Serbian and English. Analysis of potential differences in national hypertension clinical practice guidelines, in the countries observed, was not performed.

\section{CONCLUSION}

The results of this paper indicate the increase in the consumption of the drugs from the analyzed group (the C09 ATC group - drugs acting on RAS), while the demonstrated differences in the type of drugs consumed, between Serbia and the Nordic countries, indicate the need for aligning Serbian national practice with practices implemented in countries with developed pharmacotherapy. Future research should investigate the economic justification and the effects on health of such a consumption of the analyzed drugs, for the purpose of implementing the obtained results into clinical practice guidelines.

Conflict of interest: None declared.

3. Mills KT, Stefanescu A, He J. The global epidemiology of hypertension. Nature Reviews Nephrology. 2020:1-5.

4. Song P, Zhang Y, Yu J, Zha M, Zhu Y, Rahimi K, et al. Global Prevalence of Hypertension in Children: A Systematic Review and Meta-analysis. JAMA pediatrics. 2019; 173(12):1154-63.

5. Holmen J, Holmen TL, Tverdal A, Holmen OL, Sund ER, Midthjell K. Blood pressure changes during 22-year of follow-up in large general population the HUNT Study, Norway. BMC Cardiovascular Disorders. 2016; 16(1):94. 
6. Kastarinen M, Antikainen R, Peltonen M, Laatikainen T, Barengo NC, Jula A, et al. Prevalence, awareness and treatment of hypertension in Finland during 1982-2007. Journal of Hypertension. 2009; 27(8):1552-9.

7. Sjøl A, Thomsen KK, Schroll M. Secular trends in blood pressure levels in Denmark 1964-1991. International Journal of Epidemiology. 1998; 27(4):614-22.

8. Grujić V, Dragnić N, Kurgić S, Šušnjević S, Grujić J, Travar S. Epidemiology of Hypertension in Serbia: Results of a National Survey. Journal of Epidemiology. 2012; 22(3):261-6.

9. Institut za javno zdravlje Srbije „Dr Milan Jovanović Batut". Zdravstveno-statistički godišnjak Republike Srbije 2018. 2019. [citirano 10.06.2020.]. Dostupno na: http://www.batut.org.rs/download/publikacije/pub2018.pdf

10. Republička stručna komisija za izradu i implementaciju vodiča u kliničkoj praksi, Ministarstvo zdravlja Republike Srbije. Agencija za akreditaciju zdravstvenih ustanova Srbije. Nacionalni vodič dobre kliničke prakse za dijagnostikovanje i lečenje arterijske hipertenzije. 2011. [citirano 18.04.2020.]. Dostupno na: https://www.zdravlje.gov.rs/view_file.php?file_id=667\&cache=sr

11. Williams B, Mancia G, Spiering W, Agabiti Rosei E, Azizi M, Burnier M, et al. 2018 ESC/ESH Guidelines for the management of arterial hypertension: The Task Force for the management of arterial hypertension of the European Society of Cardiology (ESC) and the European Society of Hypertension (ESH). European Heart Journal. 2018; (33):3021-104.

12. Gradman AH, Basile JN, Carter BL, Bakris GL, American Society of Hypertension Writing Group. Combination therapy in hypertension. Journal of the American Society of Hypertension. 2010; 4(2):90-8.

13. Perić DM, Milijašević $D S$, Tomić $N Z$, Knežević AD, Bukumirović NR, Milijašević BŽ. Use of ACE-Inhibitors in Serbia in 2009 and 2010. Hospital Pharmacology-International Multidisciplinary Journal. 2014; 1(3):122-9.

14. Tomas $A$, Tomić Z, Milijašević $B$, Ban $M$, Horvat 0 , Vukmirović S, et al. Patterns of prescription antihypertensive drug utilization and adherence to treatment guidelines in the city of Novi Sad. Vojnosanitetski pregled. 2016; 73(6):531-7.

15. Republika Srbija. Agencija za lekove i medicinska sredstva Srbije. Promet i potrošnja gotovih lekova za humanu upotrebu u Republici Srbiji u 2010. godini. Agencija: Beograd, 2011.

16. Republika Srbija. Agencija za lekove i medicinska sredstva Srbije. Promet i potrošnja gotovih lekova za humanu upotrebu u Republici Srbiji u 2011. godini. Agencija: Beograd, 2012.

17. Republika Srbija. Agencija za lekove i medicinska sredstva Srbije. Promet i potrošnja gotovih lekova za humanu upotrebu u Republici Srbiji u 2012. godini. Agencija: Beograd, 2013.

18. Republika Srbija. Agencija za lekove i medicinska sredstva Srbije. Promet i potrošnja gotovih lekova za humanu upotrebu u Republici Srbiji u 2013. godini. Agencija: Beograd, 2014.
19. Republika Srbija. Agencija za lekove i medicinska sredstva Srbije. Promet i potrošnja gotovih lekova za humanu upotrebu u Republici Srbiji u 2014. godini. Agencija: Beograd, 2015.

20. Republika Srbija. Agencija za lekove i medicinska sredstva Srbije. Promet i potrošnja gotovih lekova za humanu upotrebu u Republici Srbiji u 2015. godini. Agencija: Beograd, 2016.

21. Norwegian Institute for Public Health. Drug Consumption in Norway 2010 2015. [citirano 18.04.2020.]. Dostupno na: http://www.legemiddelforbruk. no/english

22. Finnish Medicines Agency. Drug Consumption in Finland 2010-2015. [citirano 18.04.2020.]. Dostupno na: http://www.fimea.fi/laaketieto/kulutustiedot

23. The Danish Health Data Authority. Drug Consumption in Denmark 2010 2015. [citirano 18.04.2020.]. Dostupno na: http://www.medstat.dk/en

24. World Health Organization. Introduction to Drug Utilization Research. 2003. [citirano 11.06.2020.]. Dostupno na: https://www.whocc.no/filearchive/publications/drug_utilization_research.pdf

25. Jakovljević V, Sabo A, Tomić Z, Milijašević B. ATC klasifikacija lekova sa definisanim dnevnim dozama za lekove u prometu. Novi Sad. Orto Medics; 2007.

26. Scholze J, Bida M, Hansen A, Juncken D, Rangoonwala B, Ritz A, et al. Initiation of hypertension treatment with a fixed-dose combination or its monocomponents-does it really matter?. International Journal of Clinical Practice. 2006; 60(3):265-74.

27. Katzung BG, Masters SB, Trevor AJ. Temeljna i klinička farmakologija. 11. Izdanje. Zagreb: Medicinska naklada; 2011.

28. Patel A, MacMahon S, Chalmers J, Neal B, Woodward M, Billot L, et al. ADVANCE Collaborative Group. Effects of a fixed combination of perindopril and indapamide on macrovascular and microvascular outcomes in patients with type 2 diabetes mellitus (the ADVANCE trial): a randomised controlled trial. Lancet. 2007; 370(9590):829-40.

29. Mancia G, De Backer G, Dominiczak A, Cifkova R, Fagard R, Germano G, et al. 2007 Guidelines for the management of arterial hypertension: The Task Force for the Management of Arterial Hypertension of the European Society of Hypertension (ESH) and of the European Society of Cardiology (ESC). Journal of Hypertension; 25(6): 1105-87.

30. Gu Q, Burt VL, Dillon CF, Yoon S. Trends in Antihypertensive Medication Use and Blood Pressure Control Among United States Adults With Hypertension: The National Health and Nutrition Examination Survey, 2001 to 2010. Circulation. 2012; 126(17):2105-14.

31. Park C, Wang G, Ng BP, Fang J, Durthaler JM, Ayala C. The uses and expenses of antihypertensive medications among hypertensive adults. Research in Social and Administrative Pharmacy. 2020; 16(2):183-9.

32. Kucan M, Mrsic-Pelcic J, Vitezic D. Antihypertensive Drugs in Croatia: What Changes the Drug Usage Patterns?. Clinical Therapeutics. 2018; 40(7):1159-69. 